\title{
Does Competency, Commitment, and Internal Control Influence Accountability?
}

\author{
Pancawati HARDININGSIH*, Udin UDIN**, Greg. N. MASDJOJO***, Ceacilia SRIMINDARTI****
}

\author{
Received: February 9, 2020 Revised: February 24, 2020 Accepted: March 1, 2020.
}

\begin{abstract}
This study aims to analyze the influence of apparatus resources, organizational commitment, internal control on the accountability of village fund allocations with the level of education as a moderating. Accountability analysis of village fund allocation is carried out at every stage of planning, implementation stage, administration stage, reporting stage, and accountability stage. The study was conducted in 18 villages in Undaan District, Kudus Regency - Indonesia, with a total sample of 115 village officials. Structural Equation Model analysis techniques with Warp Partial Least Square were used to test the research hypotheses. The results showed that apparatus resources, organizational commitment, and internal control had a positive effect on the accountability of village fund allocations. The level of education strengthens the influence of apparatus resources on the accountability of village fund allocations. The findings of the study further prove that commitment has positive implications for achieving accountability. It means that the higher the commitment made by the government apparatus, the better and higher the effect on accountability in managing public funds. With an ethical commitment of the government apparatus in managing the budget, the use of funds can be in accordance with the planning and designation so that goals can be achieved.
\end{abstract}

Keywords: Organizational Commitment, Internal Control, Village Fund Allocation Accountability

JEL Classification: D23, F38, H83

\section{Introduction}

Village fund allocation is funds allocated from the district or city government to villages and transferred through the district or city budget (APBD), then transferred to the village through the APBDes (Village Budget and Revenue). The existence of the Village Fund Allocation

*First Author. Business and Economic Faculty, Universitas Stikubank, Indonesia. Email: pancawati@edu.unisbank.ac.id

${ }^{* *}$ Corresponding Author. Business and Economic Faculty, Universitas Muhammadiyah Yogyakarta, Indonesia [Postal Address: Jl. Brawijaya, Tamantirto, Kec. Kasihan, Yogyakarta, 55183, Indonesia] Tel: (+62) 85343709228

Email: udin_labuan@yahoo.com

***Business and Economic Faculty, Universitas Stikubank, Indonesia

****Business and Economic Faculty, Universitas Stikubank, Indonesia

(c) Copyright: The Author(s)

This is an Open Access article distributed under the terms of the Creative Commons Attribution Non-Commercial License (http://Creativecommons.org/licenses/by-nc/4.0/) which permits unrestricted noncommercial use, distribution, and reproduction in any medium, provided the original work is properly cited.
(VFA) hopes the village government can develop into a developed and independent region (Pemerintah, 2014). A proper VFA management so that it can be used correctly and in accordance with its designation requires a management mechanism consisting of five stages: the planning stage, the implementation stage, the administration stage, the reporting stage, and the accountability stage (Permendagri, 2014).

The existence of this mechanism, the village government, must apply the principle of accountability in managing the allocation of village funds. Accountability is an obligation to report and be responsible for the success or failure of the implementation of the organization's mission in achieving the results that have been set regularly (Mardiasmo, 2009). Likewise, the implementation of VFA in one of the districts of South Dolo, Sigi Regency, has been managed accountably and transparently. However, the application of the principle of accountability at this stage is only limited to physical accountability, and administratively it has not been thoroughly carried out correctly because it has not fully met the provisions (Irma, 2015). Such 
conditions may also occur in villages in other regions far from the reach of local governments.

The accountability of VFA management will create good governance and can improve the quality of public services. Accountability of VFA management is not only determined by the mechanism of managing village fund allocation in 5 (five) stages. However, also the support of apparatus resources that have the ability and competence is vital in managing VFA (Kholmi, 2016). The problem of apparatus resources is also a significant obstacle in villages in South Dolo sub-district, Sigi Regency, that local government officials and human resource competencies have not been optimized. As such, it is necessary to assist local government officials in basic sustainable skills programs (Irma, 2015; Purnomo, Rahayu, Riani, Suminah, \& Udin, 2020).

To form an excellent apparatus resource, each officer must commit to the organization. The existence of organizational commitment, the apparatus resources will be more responsible for the management of VFA to achieve accountability in accordance with applicable rules. This commitment also occurred to the Ketindan Village government by complying with and following the stages and provisions in accordance with the Regulations issued by the Regent of Malang. However, in practice, there are still problems that the percentage exceeds the specified amount. Furthermore, several programs were not listed at the planning stage of the RPD but appeared in the realization of its finances (Fajri, 2015). The same thing also happened to the Government of the Kerepkidul Village, Bagor Subdistrict, Nganjuk Regency has proven its commitment or responsibility by complying with and following the stages and provisions in accordance with the Regulations issued by the Nganjuk Regent but also happened similarly to Ketindan Village, the amount exceeds that of has been agreed (Indrian, 2016). Such conditions indicate that the importance of program activities must be planned and managed correctly and must be agreed upon by all citizens as a form of organizational commitment.

Although the commitment between local government and village government has been established, the implementation of VFA requires internal control. The existence of internal control, the use of village funds, can be managed properly, and the village government can achieve a level of accountability in its management in accordance with applicable regulations. Internal control is carried out by the village government and is expected to produce responsible management.

Similar conditions also occurred in Kudus, especially Undaan sub-district, which experienced an increase in village fund receipts from 2016 amounting to Rp. 81.22 billion, and in 2017 was 103.6 billion. However, the increase was not matched by the quality of human resources in managing the allocation of village funds, where there are still some village apparatuses that are still low in competence and knowledge. The low level of education possessed influences the management of village funds. This condition is also evident in some villages that do not implement a transparency system in receiving VFA and the problem of delays in disbursing village funds. For this reason, the government needs to provide more supervision so that the implementation and management of VFA are in accordance with the prevailing laws and regulations.

Several studies on village fund accountability still show mixed results. Husna and Abdullah (2016) found that resources in Pidie District had an effect on accountability. However, there is only one village out of 8 that is constrained by human resources. Likewise, Ardani (2015); Azkia and Darwanis (2016); Suherwan and Kamaliah (2017); Indrayani et al. (2017); and Yesinia, Yuliarti, and Puspitasari (2018) that apparatus resources have a significant positive effect on the accountability of ADD management. Febriani (2015); Nguyen and Tu (2020); Suherwan and Kamaliah (2017); and Mada, Kalangi, and Gamaliel (2017) prove that organizational commitment influences the performance accountability of government agencies. On the contrary, Rahayuni (2012) did not find an organizational commitment to influence accountability.

Wardana (2016); Purbasari and Bawono (2017); Widyatama, Novita, and Diarespati (2017); dan Yesinia et al. (2018) found that the internal control system had a positive effect on the accountability of regional financial management. On the contrary, Dewi, Ramadhanti, and Wiratno (2016) found that the internal control system harmed the financial performance of local governments, whereas Mutmainah and Pramuka (2017) found that internal control did not affect village funds accountability.

Sugiarti and Yudianto (2017) and Mada et al. (2017) found that the competence of local government apparatuses influences the performance of government agencies. However, the opposite results were Zirman and Rozi (2010) has not affected the accountability of the performance of government agencies. Widyatama et al. (2017) found the competence of local government apparatus did not modify the accountability of the performance of government agencies. Likewise, Ferina (2016) stated that the readiness of human resources is still not enough due to lack of socialization and lack of training on village financial management.

The novelty of this research is by including the level of education as a moderating variable. This research is expected to have a contribution to the village government as an evaluation material in order to improve the accountability and transparency of village government financial reports for the community as a means of information about accountability and transparency 
occurring in the regions. Based on the many research results, the purpose of this study is to analyze the influence of apparatus resources, organizational commitment, internal control on VFA accountability with educational levels moderating the impact of apparatus resources on VFA accountability.

\section{Literature Review}

This study uses a stewardship theory approach. Stewardship theory illustrates that there is no motivated management situation for individual goals but instead is more focused on the purpose of organizational interests. The theory assumes that there is a strong relationship between satisfaction and organizational success. In this case, organizational success illustrates the maximization of the utility of a group of principals and management. This maximization will ultimately maximize the interests of individuals in the group of the organization (Donaldson \& Davis, 1991; Nguyen \& Nguyen, 2020).

In this theory, the government acts as a steward and has no desire to fulfill personal interests. However, prioritizing the fulfillment of community needs which is also called the principal, avoids a conflict of interest between the steward and the principal who runs the executive function of the organization. Steward will be more concerned with public trust, and the underlying thing is the principle that stewards feel they have a great responsibility in managing the allocation of available resources wisely and carefully in order to carry out services to the needs of the wider community. For this reason, stewards are not motivated to meet personal desires, but instead meet the needs of the wider community, so that self-actualization is seen in public trust.

Village government (stewards) as an institution that can be trusted by the community in carrying out their duties according to their functions in the public interest, making village financial accountability, providing public services, and community welfare can be achieved to the maximum. To carry out responsibility for the principal (community), the village government (stewards) conducts an internal control system to produce quality financial statement information.

\section{Hypothesis Development}

\subsection{Effect of Apparatus Resources on Village Fund Allocation Accountability}

Apparatus resources are the ability of the apparatus to do work and essential components to improve the performance of the village government. Therefore, apparatus resources must have competence in the management of VFA to realize accountability. The relationship of apparatus resources with VFA accountability can be explained by stewardship theory, that executives as managers have a role in carrying out the mandate to achieve organizational goals within the scope of the village government.

Apparatus competence is a personal aspect of a worker that enables a person to achieve excellent performance. These individual aspects include the nature, motives, value systems, attitudes, knowledge and skills where competence will direct the behavior, then the behavior will produce performance. Apparatus competency becomes a vital factor considering capability is an internal factor and expresses in performance. Thus the management of village funds requires the skills or skills of its managers so that the accountability or accountability of the village government in managing village finances is in accordance with the mandate and trust given to it. Being responsible means managing finances well, honestly, not misusing.

This opinion is in line with Husna and Abdullah (2016) that the entire village apparatus in Pidie district is ready in village management, but there are few obstacles, namely the lack of reliable human resources and understanding of village finances. Likewise, Aziiz and Prastiti (2019); Mada et al. (2017); Azkia and Darwanis (2016); and Fajri (2015) found that the readiness of apparatus resources had a positive effect on VFA accountability. Thus,

H1: Apparatus resources have a positive effect on VFA accountability

\subsection{Effect of Organizational Commitment on Village Fund Allocation Accountability}

Organizational commitment is a crucial component of creating accountability. Organizational commitment as a degree where employees believe and accept the goals of the organization and will remain or will not leave the organization (Mathis \& Jackson, 2011). So that commitment is the ability and willingness of a person to align personal behavior with the needs, priorities and goals of the organization, it involves ways to develop goals or meet the needs of the organization which essentially puts the mission of the organization rather than personal interests.

Organizational commitment in the village government manifested in the management of village funds can be carried out correctly and in accordance with regulations, it is in line with Law No. 6 of 2014 that the implementation of the Village Revenue Expenditure Budget (VREB) with VFA as a component must be managed with high 
commitment by the executive apparatus at the village level, with a high commitment to the village government to encourage successful accountability in the management of VFA (Mada et al., 2017). MacLean (2011) states that support for organizational commitment affects accountability standards. Febrian (2015); Mada (2017); and Suherwan and Kamaliah (2017) state that organizational commitment influences the successful implementation of VFA accountability. Thus,

H2: Organizational commitment has a positive effect on VFA Accountability

\subsection{Effect of Internal Control on Village Fund Allocation Accountability}

Effect of Internal Control on Village Fund Allocation Accountability Implementation of activities in a government ranging from planning, implementation of supervision to responsibility must be carried out in an orderly, controlled, and efficient and effective manner. For this reason, a system is needed that can provide adequate confidence that the implementation of activities in a government agency can achieve its objectives efficiently and effectively, report financial management reliably, secure assets and encourage compliance with laws and regulations. This system is known as the internal control. Internal control is an essential factor in government so that the actions or efforts carried out by the leadership and the entire village apparatus can provide confidence for the achievement of organizational goals through effective and efficient activities, reliability of financial reporting and compliance with laws and regulations.

Internal control within the scope of the village government, it is hoped that the use of village funds can be appropriately managed and accountably according to statutory regulations. Aikins (2011), Wardana (2016), Widyatama (2017), and Yesinia et al. (2018) found that the internal control system had a positive and significant effect on village financial management accountability. It shows that the better the system of internal control will affect the accountability of village financial management. The stewardship approach in carrying out contracts or responsibilities towards the principal (community) then the village government (steward) conducts an internal control system to provide accountability, present, report and disclose all activities and activities that are the responsibility of the village government to the trust provider who has rights and authority to hold that accountable. So that the village government (stewards) as an institution that can be trusted by the community to carry out responsibility for all its activities can produce quality financial information reports. Thus,
H3: Internal control has a positive effect on VFA accountability.

\subsection{Education Level Moderates the Effect of Apparatus Resources on Village Fund Allocation Accountability}

Apparatus resources are the ability of village officials to carry out work and essential components to improve village government performance. Therefore, the resources of the village apparatus must have competence in the management of VFA. With competencies held by village officials and supported with an adequate level of education, it can help the realization of VFA management accountability starting from the planning stage, the implementation stage, the administration stage, the reporting stage, and the accountability stage. The education of village officials can be obtained through formal education as well as the expertise and skills possessed through the technical guidance which is held by the local government regularly then it will support in creating accountability reports (Nguyen \& Nguyen, 2020). Cahyani, Hardiningsih, and Setiawati (2019) found that the level of education moderated the apparatus' resources towards village fund accountability at the planning, implementation, reporting, and accountability stages. The executive as manager has a role in achieving organizational goals in the context of the village government, namely carrying out plans according to the Village Revenue Expenditure Budget (VREB) and compiling reports on the realization of each stage. Thus,

H4: Education level strengthens the influence of apparatus resources on VFA accountability.

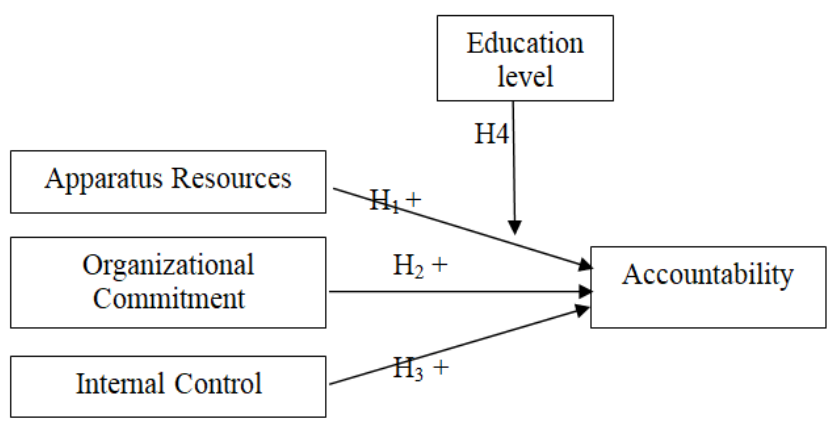

Figure 1: Research Model

\section{Research Methods}

The population of this study is all village officials who have authority in the financial management of village finances consisting of village heads, village secretaries, 
village treasurers, section heads, head of the division, and village consultative bodies in the village area of Undaan District.

The study of primary data was obtained using a written questionnaire technique to respondents relating to essential aspects in the planning stage, the implementation phase, the administration stage, the reporting stage, and the accountability stage pertaining to the research variables (Sekaran \& Bougie, 2017).

\subsection{Operational and Variable Measurement}

Apparatus resources are state administration tools that are in charge of providing public services, security services, and public order (Yoman, Pratiknjo, \& Tasik, 2016). In carrying out the tasks in the village administration, competent apparatuses must be available and able to take responsibility for the tasks given (Sanggemi, 2016).

Commitment as a condition where the individual sides with the organization and its goals and desires to maintain membership in the organization (Robbin \&Judge, 2008). Organizational commitment as a degree in which employees believe and accept the purposes of the organization and will remain or will not leave the organization (Mathis \& Jackson, 2011). Commitment to the organization means more than just formal membership because it includes attitudes like the organization and a willingness to strive a high level of effort for the benefit of the organization for the achievement of objectives.

Internal control is a process influenced by entities designed to provide reasonable guarantees regarding the achievement of objectives. Internal control is more influenced by human resources and information technology systems to help organizations achieve specific goals or objectives. Internal control is a way to direct, supervise, and measure the resources of an organization.

Accountability is the obligation to convey responsibility or to answer and explain the performance and actions of a person/legal entity/collective leader of an organization to those who have the right or authority to request information or accountability.

Hypothesis testing uses the technique of Structural Acquisition Models analysis with Warp Partial Least Square (Warp PLS). This technique was chosen because it can conclude directly about the effect of partially independent variables on the dependent variable with moderation. Another reason is that the method can be used in a limited number of study samples (Latan and Ghozali, 2014). The equation of the research model is as follows:

ACCOUNT $=a+b_{1} A R+b_{2} \mathrm{OC}+b_{3} \mathrm{IC}+\mathrm{b}_{4} \mathrm{AR} *$ $\mathrm{EL}+e$
ACCOUNT is accountability, AR is apparatus resources, OC is the organizational commitment, IC is internal control, and EL is education level.

\section{Results}

The description of respondents based on their position consists of the village head, village secretary, village treasurer, section chief, head of the division, and regional consultative body, as shown in Table 1.

Table 1: Characteristics of Respondents Based on Position

\begin{tabular}{|c|c|c|}
\hline Frequency & Person & Percentage \\
\hline Village Head & 18 & $15,65 \%$ \\
\hline Village Secretary & 16 & $13,91 \%$ \\
\hline Village Treasurer & 10 & $8,69 \%$ \\
\hline Section Chief & 33 & $28,69 \%$ \\
\hline Head of division & 26 & $22,61 \%$ \\
\hline Regional Consultative Body & 12 & $10,43 \%$ \\
\hline & 115 & $100 \%$ \\
\hline
\end{tabular}

Based on the order of village officials, most respondents were section heads and heads of division. The suitability of the results and quality test of the research model is in Table 2 of the model fit and quality indices.

Table 2: Model Fit and Quality Indices

\begin{tabular}{|c|c|}
\hline Indices & Value \\
\hline Average path coefficient (APC) & $0.188, \mathrm{P}=0.009$ \\
\hline Average R-squared (ARS) & $0.229, \mathrm{P}=0.003$ \\
\hline Average adjusted R-squared (AARS) & $0.201, \mathrm{P}=0.006$ \\
\hline Average block VIF (AVIF) & 1.387, ideally $<=3.3$ \\
\hline Average full collinearity VIF (AFVIF) & 1.506, ideally $<=3.3$ \\
\hline Tenenhaus GoF (GoF) & 0.362, large $>=0.36$ \\
\hline Sympson's paradox ratio (SPR) & 0.750, acceptable if $>=0.7$ \\
\hline R-squared contribution ratio (RSCR) & 0.932, acceptable if $>=0.9$ \\
\hline Statistical suppression ratio (SSR) & 0.750, acceptable if $>=0.7$ \\
\hline $\begin{array}{c}\text { Nonlinear bivariate causality direction } \\
\text { ratio (NLBCDR) }\end{array}$ & 0.750, acceptable if $>=0.7$ \\
\hline
\end{tabular}

From Table 2 the general output can be seen that the model has a good fit, where the p-value for Average Path Coefficient (APC) is 0.009, Average R-squared (ARS) with p-value of 0.003, and Average adjusted R-squared (AARS) with p-value of 0.006 with APC value $=0.188$, ARS value $=0.229$ and AARS value $=0.201$. Likewise, the value of Average block VIF (AVIF) and Average full collinearity VIF (AFVIF) generated is $<3.3$ meaning there is no 
multicollinearity problem between indicators and between exogenous variables. Tenenhaus GoF (GoF) produced $0.362>0.36$ which means that the model fits very well. For the Sympson's paradox ratio (SPR) index, the R-squared contribution ratio (RSCR) produces a value equal to 1 which means there is no causality problem in the model. Likewise, the Statistical suppression ratio (SSR) is 0.750> 0.7 . As for the non-linear bivariate causality direction ratio (NLBCDR) index, the value of $0.750>0.7$ means that there is a non-linear causality relationship in the model.

The validity test of the research instrument variable was shown from the results of loading factor analysis on the combined output loadings and cross-loadings, the reliability indicators of the constructor items of the dimensions of the apparatus resource dimensions, organizational commitment, internal control, education, and accountability of the planning stage, implementation stage, administration stage, the reporting stage, and the VFA response stage show that everything is valid with the resulting factor loading value $>0.7$ and the $p$-value $<0.001$.

Hypothesis test results of partial testing and moderation testing can be seen in Table 3 path coefficients and $p$ values.

Table 3: Path Coefficients and $P$ Value

\begin{tabular}{|c|c|c|c|c|}
\hline $\begin{array}{c}\text { Path coefficients } \\
\text { Account }\end{array}$ & AR & OC & IC & EL*AR \\
& 0.156 & 0.252 & 0.364 & 0.167 \\
\hline P-values & AR & OC & IC & EL*AR \\
& 0.042 & 0.002 & $<0.001$ & 0.032 \\
\hline
\end{tabular}

Output path coefficients and $\mathrm{p}$ values show that the apparatus resource (AR), organizational commitment (OC), and internal control (IC) variables have a direct and significant effect on the accountability of VFA (ACCOUNT) management with $\mathrm{p}$ values of $0.042,0.002$ and $<0.001$ and the path coefficient respectively 0.156 , 0.252 , and 0.364 . From this explanation, it is concluded that $\mathrm{H} 1, \mathrm{H} 2$, and $\mathrm{H} 3$ are supported. Furthermore, the moderating variable of education level (AR* EL) also affect the accountability of VFA management with a p-value of 0.032 and a path coefficient of 0.167 , then $\mathrm{H} 4$ is supported. It shows that education level variables have been proven to strengthen the relationship between apparatus resources (AR) and VFA management accountability (ACCOUNT).

Latent coefficients test results can be seen in Table 4 that the adjusted R-square value of 0.499 which means apparatus resources, organizational commitment, internal control, and education are able to explain the accountability of VFA management by $49.9 \%$ while the remaining $50.1 \%$ of VFA management accountability is influenced Other variables outside this research model.

The Q-square value produced by the VFA management accountability variable is $0.508>0$, which means that the model has predictive relevance. Cronbach's alpha coefficients above 0.7 for apparatus resource variables, organizational commitment, internal control, accountability and education, respectively $0.863 ; 0.736 ; 0.706 ; 0842$; and 0.869 . It shows all the reliability of all variables.

Composite reliability coefficients are above 0.7 for variable apparatus resources, organizational commitment, internal control, accountability and education, respectively $0.894 ; 0.826 ; 0810 ; 0.877$; and 0889 so as to fulfill the reliability of internal consistency.

The average variances extracted (AVE) value for each dimension is very good namely> 0.5 for the apparatus resource variable, organizational commitment, internal control, accountability and education respectively 0.519 ; $0.588 ; 0.562 ; 0.526$; and 0.529 so it meets the convergent validity.

Table 4: Latent Variable Coefficients

\begin{tabular}{|c|c|c|c|c|c|}
\hline $\mathrm{AR}$ & $\frac{\text { coeffici }}{\text { OC }}$ & IC & $\begin{array}{l}\text { ACCOUNT } \\
0.517\end{array}$ & \multicolumn{2}{|c|}{ EL*AR } \\
\hline \multicolumn{6}{|c|}{ Adjusted R-squared coefficients } \\
\hline \multirow[t]{2}{*}{$\mathrm{AR}$} & $\mathrm{OC}$ & $\mathrm{IC}$ & ACCOUNT & \multicolumn{2}{|c|}{$\mathrm{EL} * \mathrm{AR}$} \\
\hline & 0 & & 0.499 & & \\
\hline \multicolumn{6}{|c|}{ Composite reliability coefficients } \\
\hline $\mathrm{AR}$ & $\mathrm{OC}$ & IC & ACCOUNT & \multicolumn{2}{|l|}{ EL } \\
\hline 0.894 & 0.826 & 0.810 & 0.877 & \multicolumn{2}{|l|}{0.898} \\
\hline \multicolumn{6}{|c|}{ Cronbach's alpha coefficients } \\
\hline AR & $\mathrm{OC}$ & IC & ACCOUNT & \multicolumn{2}{|l|}{ EL } \\
\hline 0.863 & 0.736 & 0.706 & 0.842 & \multicolumn{2}{|l|}{0.869} \\
\hline \multicolumn{6}{|c|}{ Average variances extracted } \\
\hline $\mathrm{AR}$ & $\mathrm{OC}$ & IC & ACCOUNT & \multicolumn{2}{|l|}{ EL } \\
\hline 0.519 & 0.588 & 0.562 & 0.526 & \multicolumn{2}{|l|}{0.529} \\
\hline \multicolumn{6}{|c|}{ Full collinearity VIFs } \\
\hline $\begin{array}{l}\mathrm{AR} \\
\mathrm{EL} * \mathrm{AR}\end{array}$ & $\mathrm{OC}$ & IC & ACCOUNT & \multicolumn{2}{|l|}{$\mathrm{EL}$} \\
\hline 2.169 & 1.777 & 1.769 & 1.275 & \multicolumn{2}{|l|}{1.033} \\
\hline \multicolumn{6}{|c|}{ Q-squared coefficients } \\
\hline $\mathrm{AR}$ & $\mathrm{OC}$ & IC & ACCOUNT & \multicolumn{2}{|c|}{$\mathrm{EL} * \mathrm{AR}$} \\
\hline & & & 0.508 & & \\
\hline
\end{tabular}

The value of Full collinearity VIFs for each contract is also very good, that is $<3.3$ for the apparatus resource variable, organizational commitment, internal control, accountability, and education, respectively 2,$169 ; 1,777$; 1,$769 ; 1,275 ; 1,033$; and 1,014 so there is no collinearity problem in the research model.

\section{Discussion}

Hypothesis 1 test results prove that the village apparatus has competency readiness to do work so that accountability in the management of the Village Fund Allocation that 
starts from the planning, implementation, administration, reporting, and accountability stages has proven to be well prepared. In managing the village funds the skills or skills of the managers needed, namely the village apparatus. The village head in carrying out the management of village funds is assisted by elements of the village apparatus, one of which is the village treasurer who has the task of carrying out the administration of accountability reports. The results prove that the village treasurer district Undaan always tries to understand the rules and knowledge as well as information to support his duties, especially in preparing accountability reports. It is also done by the village treasurer and other village apparatuses who always have an effort to improve their competence. Because competence is a combination of motivation, attitude, character, knowledge and abilities that must continually be enhanced. The village treasurer and other village officials regularly update the latest knowledge and regulations, especially in managing village finances to support their duties. It shows that the competence of the village apparatus is a personal aspect of the apparatus that enables a person to achieve excellent performance. Such conditions support the opinion of Sedarmayanti (2015) that competence is a part of a deep and inherent personality in a person, as well as predictable behavior in a variety of circumstances and work assignments.

In realizing accountability in the management of village funds must be supported with adequate resources so that goals can be realized. Without individuals who have expertise or competence, the organization cannot achieve its goals. This statement is in line with Yusuf (2015) that resources as a tool to achieve goals or the ability to benefit from opportunities that exist. Likewise also supports the statement of Werther (1996) that human resources are employees who are ready, capable and alert in achieving organizational goals. This finding is in line with Husna and Abdullah (2016), Irma (2015), and Mada et al. (2017) that the competence of village officials has a positive and significant effect on the accountability of village fund management.

With these personal aspects, including nature, motives, value systems, attitudes, knowledge and skills that all of these form the competencies will direct behavior, then the behavior will produce performance. Apparatus competency becomes a vital factor considering competency is an internal factor and makes the apparatus performance better so that overall fund management accountability is also proper. In addition, the apparatus understanding in using computers in working on completing tasks also began to be effective even though it had not yet reached a high frequency. It is due to the high interest in participating in training to increase knowledge about the management of Village Fund Allocation (VFA), especially the problem of reporting the use of VFA which must be accountable to local governments. This condition also requires an adequate understanding by the village apparatuses regarding government accounting standards, especially Government Regulation No. 71 of 2010 which has begun to be adequately implemented.

In order to support the ability of village fund managers in increasing competence, the Kudus regional government fund facilitation team has several times provided training, outreach, and mentoring to village fund managers, namely the village head, village secretary, village treasurer and PTPKD. Activities carried out by the facilitation team provide direct counseling and provide consultation to village officials. This training was carried out in collaboration with the Financial and Development Supervisory Agency (DSA), which is an IT-based village financial management training, on inputting procedures using the siskeudes (village financial system) application.

Hypothesis 2 test results prove that village officials have a high commitment to the implementation of Village Budget Revenue Expenditure (VBRE) starting from the planning, implementation, administration, reporting, and accountability stages so as to support success in the success of VFA management accountability. It shows that village officials in understanding and carrying out their duties are in accordance with Law No. 6 of 2014. This condition supports the opinion of Keller (1997) that high organizational commitment significantly influences the achievement of excellent performance. Then further stated, organizational commitment can be a psychological tool in carrying out the organization to achieve the expected goals; this opinion also expressed by (Darma, 2004).

Zeyn (2011) believes that organizational commitment has a positive effect on public accountability at a moderate level. This condition shows that better organizational commitment will encourage the success of public accountability. This finding is also in line with Febriani (2015); Mada et al. (2017); and Suherwan and Kamaliah (2017) that commitment has an influence on the successful implementation of village fund allocations.

Hypothesis 3 test results prove that the use of village funds is always carried out in integrated internal monitoring of actions and activities so that the reliability of financial reporting and compliance with laws and regulations can be appropriately applied. Through internal control in the village government, it is evident that the use of village funds can be managed properly so that accountability in the management of VFA is in accordance with applicable laws and regulations. In line with what was raised by Aikins (2011) that government oversight increases financial accountability through evaluation and improvement of internal control, risk management and governance processes. 
Implementation of activities in a government ranging from planning, implementation of supervision to accountability must be carried out in an orderly, controlled and efficient and effective manner. For this reason, a system is needed that can provide sufficient confidence that the implementation of activities in the village government, in particular, can achieve goals efficiently and effectively, report financial management reliably, secure assets and encourage compliance with laws and regulations. This system is known as the Internal Control System. The Internal Control System in Government is an essential factor, because the control system can influence the internal decision making of the village government and can have implications for the accountability and transparency of the village government. This finding is in line with Wardana (2016); and Yesinia et al. (2018).

While the results of the hypothesis 4 test prove that the level of education strengthens the influence of apparatus resources on the accountability of village fund allocation, this condition demonstrates that the education of village officials also determines the accountability of VFA management. The readiness of village officials in implementing Undaan sub-district VBRE is carried out by providing knowledge and skills held by the local government about their fields of work so as not to experience difficulties and delays in work, which results in waste of materials, time, and costs.

It is done considering the educational background of the various village officials so that to unite understanding it is necessary to have a training program that is carried out routinely and intensively by the local government. The development of the village apparatus is a must that must be done continuously, following the development of the community, technological advancements, and increasing duties and authority that must be carried out. The employee development is carried out with the aim to improve the effectiveness of the work of employees in achieving predetermined work results.

In addition, local governments also provide assistance programs for each village related to VFA management. One of his tasks is to provide direction and consultation on specific issues due to the limited ability of village officials. However, in the administration stage, it turns out that it requires a more understanding of bookkeeping, even with the educational background of multidisciplinary village officials. It turns out that with a more intensive mentoring program, it can prove to strengthen accountability better. It is evidenced by conducting in-house training courses or in the form of training programs for the implementation of the siskeudes program which are routinely held by the local government reaping the hope that almost all village officials can use the application program to improve accountability.

\section{Conclusion}

The results of the study prove that commitment has positive implications for achieving accountability. It means that the higher the commitment made by the government apparatus, the better and higher the effect on accountability in managing public funds. With an ethical commitment of the government apparatus in managing the budget, the use of funds can be in accordance with the planning and designation so that goals can be achieved. However, this research study needs to increase the commitment of each government apparatus to make maximum performance and can increase the Gross Enrollment Rate (GER) as a government effort. Government planning is not yet optimal, and so is the need for training in the application of the Siskeudes program, which is carried out routinely and intensively by the local government given the educational background of the various village officials with different levels of levels.

Testing the accountability stage concludes that apparatus resources influence the planning stage up to the accountability stage. Organizational commitment influences the planning stage up to the accountability stage. Furthermore, internal control affects four stages, the implementation phase, the administration stage, the reporting stage and the accountability stage. Based on the results of testing and discussion, it can be concluded as follows:

1. Apparatus Resources has a positive effect on Village Fund Allocation Accountability.

2. Organizational commitment has a positive impact on VFA accountability.

3. Internal control has a positive impact in VFA accountability.

4. The level of education does not moderate the influence of apparatus resources on VFA accountability

The implications of the results of this study are expected to be a reference for local governments at the sub-district and district levels in conducting training and training of apparatus resources in 16 villages in the Undaan subdistrict. So that each village can increase accountability at every stage.

Some limitations in this study are that the use of technology in village financial management is still simple using applications such as Microsoft Word and Excel, but after training in the use of village financial system applications by the local government began to show significant results, although it must be routinely carried out alternately training schedules given the number of village apparatuses quite a lot. Village officials also still have difficulty in filling out the questionnaire so that several 
villages request the inquiry back because of errors in filling out or lack of completeness. Furthermore, there are still several village officials who double the task of two positions at once, especially in the village of Glagahwaru, due to the lack of resources of officials in the village. This study only uses data collection in the village government apparatus and does not come from the relevant village community and local government officials responsible for managing the village fund allocation.

Based on the limitations of existing research, some suggestions need to be followed up in further research to expand the area of research in order to get more precise results regarding the Accountability of Village Fund management. Researchers also need to develop other variables that can affect the accountability of village fund allocations so that the results are more predictable than before. It is necessary to budget the education costs in the VBRE for village officials in whole or in part given in the form of educational assistance. The regional government needs to intensify and continuously intensively socialize and train village finance officers through inhouse training to overcome the lack of understanding, capacity and expertise of village officials so that the implementation of the village funding program can run smoothly and not experience obstacles, particularly in reporting and accountability.

The next researcher is expected to be able to adjust the research questionnaire to the conditions and abilities of village officials, as well as to ensure answers from respondents to match the actual circumstances. The formulation of sentences in the questionnaire needs to be simplified in order to facilitate the understanding of village officials.

Local governments need to balance the distribution of personnel resources so that they are capable, and there should be no concurrent positions to suit their abilities better. Local governments also need to improve training and coaching in the management of village fund allocations routinely to enhance the capabilities and skills of all village government apparatus resources.

\section{References}

Aikins, S. K. (2011). An Examination of Government Internal Audit's Role in Improving Financial Performance. Journal of Public Finance and Management, 11(4), 306-337.

Ardani, N. G. (2015). Development of Village Apparatus Competency Resources through Capacity Building Strategy (Study at Bluru Kidul Village Office, Sidoarjo District, Sidoarjo Regency). Journal of Public Administration, 3(2), 275-281. Retrieved from

http://administrasipublik.studentjournal.ub.ac.id/index.php/jap /article/view/775.

Aziiz, M. N., \& Prastiti, S. D. (2019). Factors That Affect Village
Fund Accountability. Journal of Actual Accounting, 6(2), 280344. http://journal2.um.ac.id/index.php/jaa/article/view/8097.

Azkia, H. B., \& Darwanis. (2016). The Effect of Human Resources Quality and Public Accountability on Financial Management Performance in the AR-Raniry State Islamic University, Banda Aceh. Journal of Accounting, 5(4), 22-32. http://www.jurnal.unsyiah.ac.id/JAA/article/view/5727

Behnam, M., \& MacLean, T. L. (2011). Where is the accountability in international accountability standards?: A decoupling perspective. Business Ethics Quarterly, 21(1), 4572. https://doi.org/10.5840/beq20112113.

Cahyani, I., Hardiningsih, P., \& Setiawati, I. (2019). The Effect of Apparatus Resources on Accountability of Public Funds with Education as Moderating. Joint Proceedings, 978-979. Retrieved from

https://www.unisbank.ac.id/ojs/index.php/sendi_u/article/view /7342/2397.

Darma, E. S. (2004). The effect of clarity of budget targets and accounting control systems: Empirical studies in Regencies and cities throughout Yogyakarta Special Province. Yogyakarta, Indonesia: Universitas Gadjah Mada. Retrieved January 10, 2020, from http://etd.repository.ugm.ac.id/home/detail_pencarian/25728.

Dewi, R. A., Ramadhanti, W., \& Wiratno, A. (2016). Factors That Influence Financial Performance of Village Governments Post Law Enforcement. Journal of Actual Accounting, 3(4), 311327. Retrieved from http://journal.um.ac.id/index.php/jaa/index.

Donaldson, L., \& Davis, J. H. (1991). Stewardship Theory or Agency Theory: CEO Governance and Shareholder Returns. Australian Journal of Management, 16(1), 49-64. https://doi.org/10.1177/031289629101600103.

Fajri, R. (2015). Village Government Accountability in Village Fund Allocation Management (Study at Ketindan Village Office, Lawang District, Malang Regency). Journal of Public Administration, 3(7), 1099-1104. Retrieved from http://administrasipublik.studentjournal.ub.ac.id/index.php/jap /article/view/920.

Febriani. (2015). The Effect of Good Governance, Compensation, Organizational Commitment, Motivation, Work Environment on the Accountability of Government Agencies Performance (SKPD Bintan Regency Government). Surakarta, Indonesia: Universitas Sebelas Maret. Retrieved January 10, 2020, from https://digilib.uns.ac.id/dokumen/detail/42662/CorporateGovernance-Dan-Manajemen-Laba-Bank-Umum-SyariahBus-Di-Indonesia-Tahun-2007-2012.

Ferina, I. S., \& Lubis, H. (2016). Review of Village Government Readiness in Implementing Minister of Domestic Affairs Regulation No. 113 of 2014 concerning Village Financial Management (Case Study of Village Government in Ogan Ilir Regency). Sriwijaya Business and Management Journal, 14(3), 321-336. Retrieved from https://ejournal.unsri.ac.id/index.php/jmbs/article/view/3991.

Husna, S., \& Abdullah, S. (2016). The readiness of the village apparatus in carrying out village financial management in an accountable manner in accordance with Law number 6 of 2014 on villages (study in several villages in Pidie district). Scientific Journal of Accounting Economics Students, 1(1), 282-293. Retrieved from 
http://www.jim.unsyiah.ac.id/EKA/article/view/774.

Indrayani, L. F., Diatmika, P. D., \& Wahyuni, M. A. (2017). The Influence of Organizational Commitment, Clarity of Budget Objectives and Effectiveness of Internal Control on Accountability of Public Organizational Performance (Empirical Study on Regional Work Unit of Gianyar Regency). Accounting Student Scientific Journal, 8(2). http://dx.doi.org/10.23887/jimat.v8i2.10463.

Indrian, S. (2016). Accountability of Village Government Implementation in Managing Village Budgeting (APBDes). EXISTS. Journal of Economic and Business Research, 11(2), 190-199. Retrieved from

http://ejournal.stiedewantara.ac.id/index.php/001/article/view/ 48.

Irma, A. (2015). Accountability in Village Fund Allocation Management in Dolo Selatan District, Sigi Regency. Journalist Journal, 3(1), 121-137. Retrieved from http://jurnal.untad.ac.id/jurnal/index.php/katalogis/article/view 14254.

Keller, R. T. (1997). Job Involement and Organizational Commitment as Longitudinal Predictor of Job Performance: A Study of Scietest and Engineers. Journal of Psychology, 82(4), 539-545. Retrieved from https://psycnet.apa.org/record/199705398-008.

Kholmi, K. M. (2017). Accountability in managing village fund allocation (study in Kedungbetik village, Kesamben district, Jombang). Journal of Innovation in Business and Economics, 7(2), 143-152. Retrieved from http://202.52.52.22/index.php/jibe/article/view/3421.

Latan, H., \& Ghozali, I. (2014). Partial Least Squares. Concepts, Methods and Applications Using the WarpPLS 5.0. Semarang, Indonesia: Badan Penerbit Universitas Diponegoro.

Mada, S., Kalangi, L., \& Gamaliel, H. (2017). The Effect of Competence of Village Fund Managers, Commitment of Village Government Organizations, and Community Participation in Village Fund Management Accountability in Gorontalo District. Scientific Journal of the Faculty of Economics Accounting, 8(2), 106-115. Retrieved from https://ejournal.unsrat.ac.id/index.php/goodwill/article/view/1 7199.

Mardiasmo. (2009). Public sector accounting. Yogyakarta, Indonesia: CV Andi Offset.

Mathis, R. L., \& Jackson, J. H. (2011). Human Resource Management. Jakarta, Indonesia: Salemba Empat.

Mutmainah, I., \& Pramuka, B. A. (2017). Application of Village Fund Management Accountability and Government Internal Control System (Spip) in Kedungwuni District, Pekalongan Regency. Journal of Economics, Business and Accounting, 19(4), 1-12. Retrieved from http://www.jp.feb.unsoed.ac.id/index.php/jeba/article/view/1104.

Nguyen, T. H., \& Tu, V. B. (2020). Social Responsibility, Organizational Commitment, and Organizational Performance: Food Processing Enterprises in the Mekong River Delta. Journal of Asian Finance, Economics and Business, 7(2), 309-316. https://doi.org/10.13106/jafeb.2020.vol7.no2.309.

Nguyen, T. N. L., \& Nguyen, V. C. (2020). The Determinants of Profitability in Listed Enterprises: A Study from Vietnamese Stock Exchange. Journal of Asian Finance, Economics and
Business, 7(1), 47-58.

https://doi.org/10.13106/jafeb.2020.vol7.no1.47.

Nguyen, T. Q., \& Nguyen, H. T. T. (2020). Factors Affecting Industry and University Collaboration in Education in the Hospitality Industry in Vietnam: A Business Perspective. Journal of Asian Finance, Economics and Business, 7(2), 291300. https://doi.org/10.13106/jafeb.2020.vol7.no2.291.

Pemerintah, P. (2014). Government Regulation Regarding Village Funds Sourced From the State Budget. Retrieved January 10, 2020, from www.djpk.depkeu.go.id.

Permendagri. (2014). Permendagri 113 of 2014 Village Financial Management. Retrieved January 10, 2020, from www.keuangandesa.com.

Purbasari, H., \& Bawono, A. D. B. (2017). The Effects of Fiscal Decentralization, Internal Control Systems and Local Government Performance on Accountability of Financial Statements. Indonesian Accounting and Financial Research, 2(2), 102-108. DOI: 10.23917/reaksi.v2i2.4884.

Purnomo, S., Rahayu, E. S., Riani, A. L., Suminah, S., \& Udin, U. (2020). Empowerment Model for Sustainable Tourism Village in an Emerging Country. Journal of Asian Finance, Economics and Business, 7(2), 261-270. https://doi.org/10.13106/jafeb.2020.vol7.no2.261.

Rahayuni, R. (2012). The Influence of Organizational Culture, Organizational Commitment and Public Accountability on Organizational Performance (Study of the Department of Revenue, Financial Processing and Regional Assets of Grobogan Regency). Surakarta, Indonesia: Universitas Muhammadiyah Surakarta. Retrieved January 10, 2020, from http://eprints.ums.ac.id/22610/.

Robbin, S. P., \& Judge, T. 2008. Organizational Behavior. Jakarta, Indonesia: Salemba Empat.

Sanggemi, R. (2016). The Influence of Human Resources Competence and Public Accountability on the Performance of Government Agencies (Survey on Bandung City BPKA). Accounting Study Program - Fakultas Ekonomi Universitas Komputer Indonesia.

Sedarmayanti. (2015). Human Resource Management. Bandung, Indonesia: Refika Aditama.

Sekaran, U., \& Bougie, R. (2017). Research methodology for business. Jakarta, Indonesia: Salemba Empat.

Sugiarti, E., \& Yudianto, I. (2017). Analysis of Human Resource Competency Factors, Utilization of Information Technology, and Budgeting Participation in Village Fund Management Accountability (Survey of Villages in Klari District, East Karawang District, Majalaya District and Rengasdengklok District Karawang Regency). Retrieved January 10, 2020, from http://localhost:8080/xmlui/handle/123456789/8578.

Suherwan, S., \& Kamaliah, K. (2017). Analysis of Factors Affecting Successful Implementation of Village Fund Allocation (Case Study in South Siantan District, Anambas Islands District). Journal of Boxing Business Management, 9(2), 201-214.

https://jtmb.ejournal.unri.ac.id/index.php/JTMB/article/view/4 915.

Wardana, I. (2016). Accountability in village financial management (study of village government in Magelang District). Semarang, Indonesia: Universitas Negeri Semarang. Retrieved January 10, 2020, from: 
https://lib.unnes.ac.id/24614/.

Werther Jr, W. B., \& Davis, K. (1996). Human Resources and Personal Management. Singapore: McGrew-Hill.

Widyatama, A., Novita, L., \& Diarespati, D. (2017). The Effect of Competence and Internal Control Systems on Village Government Accountability in Managing Village Fund Allocation (ADD). Indonesian Periodical Journal of Accounting and Finance, 2(2), 1-20. https://ejournal.unair.ac.id/BAKI/article/view/4762.

Yesinia, N. I., Yuliarti, N. C., \& Puspitasari, D. (2018). Analysis of Factors Affecting Accountability in Village Fund Allocation Management (Case Study in Yosowilangun District, Lumajang Regency). Journal of Assets (Research Accounting), 10(1), 105-112. doi: https://doi.org/10.17509/jaset.v10i1.13112

Yoman, M., Pratiknjo, M. H., \& Tasik, F. (2016). Quality of Apparatus Resources in Achieving Development Goals in Yamo District, Puncak Jaya Regency, Papua Province. Journal of Public Administration, 3(4), 1-9.
https://ejournal.unsrat.ac.id/index.php/JAP/article/viewFile/13 $690 / 13272$

Yusuf, B. (2015). Human Resource Management in Islamic Financial Institutions. Jakarta, Indonesia: PT. Raja Grafindo Persada.

Zeyn, E. (2011). The effect of good governance and government accounting standards on financial accountability with organizational commitment as a moderator. Journal of Accounting and Finance Review, 1(1), 21-36. Retrieved from http://ejournal.umm.ac.id/index.php/jrak/article/view/497.

Zirman, Darlis, E., \& Rozi, R. M. (2010). The Influence of Competence of Local Government Apparatus, Application of Financial Accountability, Work Motivation, and Obedience to Laws and Regulations on Performance Accountability of Government Agencies. Journal of Economics, 18(1), 1-12. Retrieved from https://je.ejournal.unri.ac.id/index.php/JE/article/view/742. 